\title{
A survey on the relationship between stock liquidity with firm performance: A case study of Tehran Stock Exchange
}

\author{
Hasan Ghalibaf Asle ${ }^{\mathrm{a}}$, Mohammad Khodaei Valahzaghard ${ }^{\mathrm{b} *}$ and Babak Asadi Ahranjani ${ }^{\mathrm{c}}$
}

\begin{abstract}
${ }^{a}$ Assist. Prof. \& Faculty Member, Department of Management, Faculty of Social sciences and Economics, Azahra University, Tehran, Iran
${ }^{b}$ Assist. Prof. \& Faculty Member, Department of Accounting, School of Management and Human Sciences, Tehran North Branch, Islamic Azad University (IAU), Tehran, Iran

${ }^{c}$ M.A. Student, Faculty of financial sciences, University of Economic Sciences, Tehran, Iran

C H R O N I C L E

Article history:

Received October 15, 2012

Received in revised format

1 December 2012

Accepted 2 December 2012

Available online

December 62012

Keywords:

Tobin's $Q$

\section{A B S T R A C T}

Liquidity play an important role on performance of firms listed in Stock Exchange. When there is a good flow of trading stocks, people could expect more financing through absorbing investors on market. The proposed study of this paper investigates the relationship between Tobin's Q and illiquidity in some selected firms in Tehran Stock Exchange. The proposed study selects non-financial stocks over the period of 2001-2010. The result of the survey indicates that there is a negative relationship between illiquidity and Tobin's Q but the ratio is approximately seven percent. In other words, as illiquidity increases by one percent, we could expect only a small change in firms' performance.
\end{abstract}

Illiquidity

Tehran Stock Exchange

\section{Introduction}

Liquidity play an important role in performance of firms listed in Stock Exchange. When there is a good flow of trading stocks, people could expect more financing through absorbing investors on market. Admati and Pfleiderer ( 2009) investigated whether a large shareholder could ease conflicts of interest between managers and shareholders through the credible threat of exit on the basis of private data. In this model, the threat of exit often alleviated agency costs, but additional private data were not required to enhance the effectiveness of the mechanism. In addition, the threat of exit produces various impacted depending on whether the agency issue involves desirable or undesirable actions from shareholders' perspective. Agrawal et al. (2004) investigated the relationship between bid and ask and their spread by studying investors' information. Amihud and Mendelson (1986) in other study investigated the relationship between bid-ask and asset pricing.

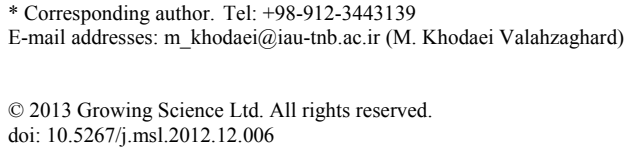


According to Amihud and Mendelson (2008), liquidity and the value of the firm could help absorb more liquidity. Amihud and Mendelson (2000), in other study, indicated that when there was more liquidity with firm, we could expect better financing with lower cost (Edmans, 2009). Amihud (2002) investigated the illiquidity and stock return using cross-section and time series analysis. Chung et al. (2010) studied the relationship between corporate governance and liquidity. Chordia et al. (2010) studied the relationship between market liquidity and trading activity and indicated that increasing the amount of trading activity could increase liquidity in the market.

Coffee (1991) performed an investigation on the relationship between liquidity and control within the context of the institutional investor as corporate monitor. Goldstein and Guembel (2008) investigated market manipulation and the allocational role of prices in stock market. Khanna and Sonti (2004) did similar investigation and discussed how price manipulation could harm long-term investment. Gompers et al. (2003) investigated corporate governance and equity prices using a comprehensive analysis on data gathered from stock market. Hasbrouck (2009) studied trading costs and returns for US equities by estimating effective costs from daily data.

Hassani and Mahdavi Sabet (2012) investigated the explanatory power of leverage and cash flows in future cash flow prediction in Tehran Stock Exchange by investigating Signaling Theory and Pecking Order Theory. They implemented the regression models of leverage and cash flow with a set of control variables based on theoretical foundations. Statistical samples included of firms listed in Tehran Stock Exchange over the period 2005-2011. The results demonstrated that there was a negative relationship between cash flow and leverage levels in contemporary time and the result was consistent with pecking order behavior.

Holmstrőm and Tirole $(1993,2001)$ investigated the effects of liquidity on performance monitoring and asset pricing. Adhami and Asghari (2013) considered the impact of block ownership on performance of firms in terms of profitability. They developed two econometric models and applied them on selected firms from Tehran Stock Exchange over the period 2002-2010. The aim was to find the relationship between return of assets and Tobin's Q as dependent variables with eight independent variables including company size, sales growth, block ownership, debt and liability ratios, etc. The results of implementation of ordinary least squares on two econometric models disclosed that while there was no meaningful relationship between return of asset and block ownership there was a meaningful relationship between block ownership and Tobin's Q.

The proposed study of this paper investigates the relationship between Tobin's Q and illiquidity. The proposed study presents details of the implementation in section 2. Section 3 presents details of the finding and concluding remarks are given in the last to summarize the contribution of the paper.

\section{The proposed study}

The proposed study of this paper investigates the relationship between Tobin's Q and illiquidity in some selected firms in Tehran Stock Exchange. The proposed study selects non-financial stocks over the period of 2001-2010. We use Amihud's method (Amihud, 2002) to measure iliquidity, which is based on Tobin Q and it is calculated as follows,

$$
\text { Illiq = mean }\left(\frac{\text { Return }_{t}}{\text { Trading Volume }_{t}}\right) \text {. }
$$

Note that this ratio is not defined zero for days with zero return but all days with zero return are considered zero. This measure is more suitable for countries where there are not much strong economical infrastructures. Tobin $\mathrm{Q}$ is one of the ways to measure the performance of different firms and it can be calculated as follows, 


$$
Q T o b i n_{i, t}=\frac{S_{-} M V_{i, t}+S T D_{-} B V_{i, t}+L T D_{-} B V_{i, t}}{T A_{-} B V_{i, t}},
$$

where $S \_M V i, t$ is market value of firm $i$ at time $t, S T D \_B V_{i, t}$ is the book value of short term debts of firm $i$ at time $t, L T D \_B V_{i, t}$ is the book value of long term liabilities of firm $i$ at time $t$ and finally $T A \_B V i, t$ is total asset book value of firm $i$ at time $t$.

In this survey, we have considered six variables including trades, active days of trading, the number of buyers, Tor, Tobin Q and illiquidity. Table 1 summaries details of mean, median, max, min and skewness.

\section{Table 1}

Indices of study variables descriptive statistics

\begin{tabular}{ccccccc}
\hline Statistical Obs. & Trades & day & buyer & Tor & tobinq & Illiq \\
\hline Mean & 4512.829 & 109.1360 & 1614.448 & 1185.125 & 3.015813 & $2.62 \mathrm{E}-07$ \\
Median & 787.0000 & 106.0000 & 359.0000 & 259.9722 & 1.308223 & $3.42 \mathrm{E}-10$ \\
Max & 171503.0 & 288.0000 & 49348.00 & 77683.24 & 2940.565 & 0.000208 \\
Min & 1.000000 & 2.000000 & 0.000000 & 0.003571 & 0.248773 & $1.10 \mathrm{E}-13$ \\
Std. dev. & 12952.77 & 70.22520 & 4169.670 & 3376.534 & 63.43678 & $5.51 \mathrm{E}-06$ \\
Skewness & 6.494640 & 0.177574 & 5.883828 & 10.66423 & 46.28108 & 31.11376 \\
Kurtosis & 57.29705 & 1.834977 & 45.96053 & 179.6223 & 2143.625 & 1064.913 \\
\hline N. of Obs. & 2147 & 2147 & 2147 & 2130 & 2147 & 2147 \\
\hline
\end{tabular}

Table 2 demonstrates correlation value along with P-value among different variables.

Table 2

Correlation values among different components and P-value for the first hypothesis

\begin{tabular}{|c|c|c|c|c|c|}
\hline & TobinQ & buyer & trades & day & Tor \\
\hline buyer & -0.044 & & & & \\
\hline P-value & 0.042 & & & & \\
\hline trades & -0.001 & 0.885 & & & \\
\hline P-value & 0.952 & 0.000 & & & \\
\hline day & -0.099 & 0.425 & 0.377 & & \\
\hline P-value & 0.000 & 0.000 & 0.000 & & \\
\hline tor & -0.449 & 0.252 & 0.210 & 0.527 & \\
\hline P-value & 0.000 & 0.000 & 0.000 & 0.000 & \\
\hline Illiq & -0.265 & 0.362 & 0.343 & 0.299 & 0.367 \\
\hline $\mathrm{P}$-value & 0.000 & 0.000 & 0.000 & 0.000 & 0.000 \\
\hline
\end{tabular}

As we can observe from the results of Table 2, there is a negative correlation between illiquidity and Tobin-Q when the level of significance is one percent. There is also a positive correlation between illiquidity and the number of buyers, number of transactions, number of trading days and trading volume. We have also used Hausman Test to find out whether we should use fixed or variable method and the test examines the following hypothesis,

$$
\left\{\begin{array}{lc}
H_{0}: & \text { Random effects } \\
H_{1}: & \text { Fixed effects }
\end{array}\right.
$$

The Hausman test calculates the following ratio to perform the test,

$$
H=n \hat{q}^{\prime}(\operatorname{Avar}(\hat{q}))^{-1} \hat{q},
$$

where $\hat{q}$ is the estimated difference for descriptive variables, Avar represents the variance of observations and $n$ is the number of observations. The results of Hausman test on cross-section random test yields Chi-Square value of 12.4421 with P-value of 0.0000 . Therefore, the null 
hypothesis is rejected and we can conclude that it is better to use fixed effect method for regression analysis.

\section{The results}

The main hypothesis of this survey examines the relationship between Tobin Q and illiquidity of firms. In order to test this hypothesis, we need to examine the following regression model,

$\operatorname{Tobin}_{i t}=\alpha_{i t}+\beta_{1 i t} I L L I Q_{i t}+\varepsilon_{i t}$

Before we use ordinary least square technique to test the model, we need to use perform panel unit root test on both independent and dependent variables to make sure the data are stationary. Table 3 demonstrates details of our findings,

Table 3

Panel unit root test on TobinQ and IlliQ

\begin{tabular}{lcccc}
\hline & \multicolumn{2}{c}{ TOBINQ } & \multicolumn{2}{c}{ ILLIQ } \\
Method & Statistic & Prob. ${ }^{*}$ & Statistic & Prob.** \\
\hline Levin, Lin \& Chu t* & -43.8208 & 0.0000 & -38.1014 & 0.0000 \\
Breitung t-stat & 2.61386 & 0.0000 & -10.5859 & 0.0000 \\
Im, Pesaran and Shin W-stat & -8.57401 & 0.0000 & -12.9885 & 0.0000 \\
ADF - Fisher Chi-square & 763.741 & 0.0000 & 1031.20 & 0.0000 \\
PP - Fisher Chi-square & 845.713 & 0.0000 & 1115.46 & 0.0000 \\
\hline
\end{tabular}

As we can observe from the results of Table 3, there is no unit root with either independent or dependent variable. The other test is learn more about the cause and effect between these two variables using cause and effect test based on Pairwise Granger Causality test. Table 4 demonstrates details of the results.

\section{Table 4}

The results of Pairwise Granger causality test

\begin{tabular}{lcc}
\hline Null Hypothesis: & F-Statistic & Prob. \\
\hline ILLIQ does not Granger Cause TOBINQ & 5.93761 & 0.0005 \\
TOBINQ does not Granger Cause ILLIQ & 4.57736 & 0.0034 \\
\hline
\end{tabular}

As we can observe from the results of Table 4, we can reject the null hypothesis and conclude that there is a two-side relationship between these two variables. We have performed a regression test on Eq. (4). Durbin-Watson is calculated as 1.13 , which means there is a correlation between the residuals. Therefore, we add a new term of $\mathrm{AR}(1)$ to remove the autocorrelation between residuals as follows,

Tobin $_{i t}=\alpha_{i t}+\beta_{1 i t} I L L I Q_{i t}+\beta_{2 i t} A R+\varepsilon_{i t}$.

Table 5 demonstrates details of the implementation of ordinary least square technique on Eq. (5).

Table 5

The results of regression analysis of using Cross-section fixed (dummy variables)

\begin{tabular}{cccc}
\hline Variable & Coefficient & t-Statistic & Prob \\
\hline C & 0.956688 & 33.82065 & 0.0000 \\
ILLIQ & -0.044286 & -5.536236 & 0.0000 \\
AR(1) & 0.423189 & 19.84599 & 0.0000 \\
\hline R-squared & F-statistic & Prob(F-statistic) & Durbin-Watson stat \\
0.634417 & 9.100198 & 0.000000 & 2.128674 \\
\hline
\end{tabular}

As we can observe from the results of Table 5, all t-student values are statistically significant, which means all individual coefficients are meaningful. Durbin-Watson is equal to 2.128674, which means 
there is no autocorrelation among independent variables. F-value is equal to 9.100 , which states there is a linear relationship between all independent variables. Finally, $\mathrm{R}^{2}=0.63$, which means the independent variables of this regression analysis present approximately $63 \%$ of the changes on dependent variable. According to Table 5, there is negative relationship between illiquidity and Tobin Q. In other words, an increase of unit in illiquidity will reduce Tobin Q by -0.044286 unit. In other words, when stock market gains more liquidity, we could expect a better performance on stock market returns.

\section{Conclusion}

In this paper, we have presented an empirical study to investigate the relationship between Tobin's Q and illiquidity in some selected firms in Tehran Stock Exchange. The proposed study selected nonfinancial stocks over the period of 2001-2010 and we have confirmed that the data were stationary. The proposed study of this paper has implemented ordinary least square technique to study the relationship between Tobin's Q and illiquidity. The result of the survey indicates that there is a negative relationship between illiquidity and Tobin's $Q$ but the ratio is on seven percent. In other words, as illiquidity increases by one percent, we could expect only a small change in firms' performance.

\section{Acknowledgment}

The authors would like to thank the anonymous referees for constructive comments on earlier version of this paper.

\section{References}

Adhami, S., \& Asghari, M.R. (2013). Block share ownership and corporate earning: Evidence from Tehran Stock Exchange. Management Science Letters, 3(1), 129-134.

Admati, A.R., \& Pfleiderer, P. ( 2009). The "wall street walk" and shareholder activism: exit as a form of voice. Review of Financial Studies, 22(7), 2645-2685.

Agrawal, V., Kothare, M., Rao, R. K., \& Pavan, W. (2004). Bid-ask spreads, informed investors, and the firm's financial condition. Journal of the Midwest Economics Association, 44(1), 58-76

Amihud, Y., \& Mendelson, H. (2008). Liquidity, the value of the firm, and corporate finance. Journal of Financial Applied Corporate Finance, 20(2), 32-45.

Amihud, Y., \& Mendelson, H. (2000). The liquidity route to a lower cost of capital. Journal of Financial Applied Corporate Finance, 12(4), 8-25.

Amihud, Y. (2002). Illiquidity and stock returns: cross-section and time- series effects. Journal of Financial Markets, 5, 31-56.

Amihud, Y., \& Mendelson, H. (1986). Asset pricing and the bid-ask spread. Journal of Financial Economics, 17, 223-249.

Chung, K.H., Elder, J., \& Kim, J.C. (2010). Corporate governance and liquidity. Journal of Financial and Quantitative Analysis, 45, 265-291.

Chordia, T., Roll, R., \& Subrahmanyam, A. (2001). Market liquidity and trading activity. Journal of Finance, 56, 501-530

Coffee, J. (1991). Liquidity versus control: the institutional investor as corporate monitor. Columbia Law Review, 91, 1277-1368.

Edmans, A. (2009). Blockholder trading, market efficiency, and managerial myopia. Journal of Finance, 64(6). 2481-2513

Goldstein, I., \& Guembel, A. (2008). Manipulation and the allocational role of prices. Review of Economic Studies, 75, 133-164. 
Gompers, P., Ishii, J., \& Metrick, A. ( 2003). Corporate governance and equity prices. Quarterly Journal of Economics, 118, 107-115.

Hasbrouck, J. (2009). Trading costs and returns for US equities: estimating effective costs from daily data. Journal of Finance, 64, 1445-1477.

Hassani, M., \& Mahdavi Sabet, E. (2012). The examination of signaling theory versus pecking order theory: Evidence from Tehran Stock Exchange. Management Science Letters, 3(1), 119-128.

Holmstrőm, B., \& Tirole, J. (1993). Market liquidity and performance monitoring. Journal of Political Economy, 101, 678-709.

Holmstrőm, B., \& Tirole, J.(2001). LAPM: liquidity-based asset pricing model. Journal of Finance, $56,1837-1867$.

Khanna, N., \& Sonti, R. (2004). Value creating stock manipulation: feedback effect of stock prices on firm value. Journal of Financial Markets, 7, 237-270. 